\title{
Hydroponics: Innovative Option for Growing Crops in Extreme Environments-The Case of the Arabian Peninsula (A Review)
}

\author{
Bello AS ${ }^{1}$, Ahmed TA² and Ben-Hamadou R ${ }^{1 *}$ \\ ${ }^{1}$ Department of Biological and Environmental Sciences, College of Arts and Sciences, \\ Qatar University, Qatar \\ 2Environmental Science Centre, Qatar University, Qatar
}

*Corresponding author: Radhouane Ben-Hamadou, Department of Biological and Environmental Sciences, College of Arts and Sciences, Qatar University, P0 Box 2713, Doha, Qatar, Tel: +97444036454; Fax: +97444034531; Email: benhamadou@qu.edu.qa

\section{Abstract}

The inexorable movements of growing population, increasing water stress, urbanization, and persistent global warming are greatly responsible for the reduction in the availability of cultivable land in the Arabian Peninsula countries where successful soil crop cultivation practically depends on scarce resources - water for irrigation. Consequently, the stakeholders are battling global food security and how to conveniently feed the persistent growing global population expected to reach 9.7 billion by 2050. Overcoming this predicament to have a bountiful harvest, improved technology as hydroponic systems is needed. The hydroponic systems result in higher yield and mitigate environmental issues associated with productions. The system's advantages include cleanliness, pests and drought control, and year round production. The concerned issues alongside benefits and limitations are evaluated in this review.

Keywords: Hydroponic systems; Food security; Phytochemicals; Agriculture; Arabian Peninsula countries

\section{Highlight}

- Food security is a critical priority for the Arabian Peninsula (AP) countries.

- Food and agricultural produce are majorly imported to provide food commodities to residents in the AP countries

- More emphasize is given to improved technology, accordingly hydroponics offer an adequate alternative as production system in the AP countries

- Adapted hydroponic systems can enhance food security in the AP countries

\section{Introduction}

By 2050, the global population is projected to attain 9.7 billion by demographers. Additionally, it is predicted that half of the fertile land worldwide will be unusable for farming [1]. Thus, the production of food commodities should be increased by as much as $110 \%$ to satisfy world population food demands. Approximately, it has been recommended that a minimum daily consumption of $400 \mathrm{~g}$ of both vegetables and fruits is expected for healthy living according to the World Health Organization (WHO) and the Food and Agriculture Organization FAO [2]. As established by the United Nation (UN), presently several 


\section{Open Access Journal of Agricultural Research}

countries are encountering food shortage, particularly in Africa. However, if there is a failure in meeting the demand, it is expected that the food crisis will extend to 2050 [1]. The crisis occurred due to the unfavorable climatic conditions resulted to drought or floods as they occur more frequently. Another reason is the persistent rise in the world population which have resulted to shift in the demand for food to be on increase. As forecasted that the World's population will attain 9.5 billion inhabitants by the year 2050, no doubt this will lead to complicated issues in term of environment and economic in order to meet energy demand for the rising population. However, water reduction in agricultural practices just to achieve or enhancing economic productivity is a serious setback in the countries of arid as well as semiarid regions. The Arabian Peninsula which comprises of Gulf Cooperation Council ; GCC (Saudi Arabia, Oman, United Arab Emirates, Kuwait, Qatar, Bahrain) [3] and Yemen belong to this region where the countries are located in desert environment with peculiar climatic parameters such as persistent high temperatures, high rate of evaporation and little rainfall according to the World Development Indicator (WDI). Hence, they heavily rely on irrigated agriculture which responsible to the largest proportion of water consumption amounted to roughly 78 percent of total water utilized in the entire GCC countries on average [4]. Agricultural water use relies on mostly (85\%) from groundwater resources, which are at most not renewable [4].
A.

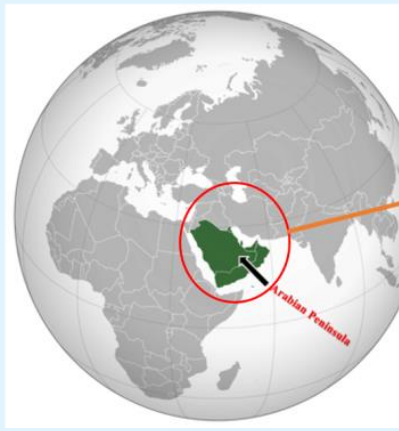

B.

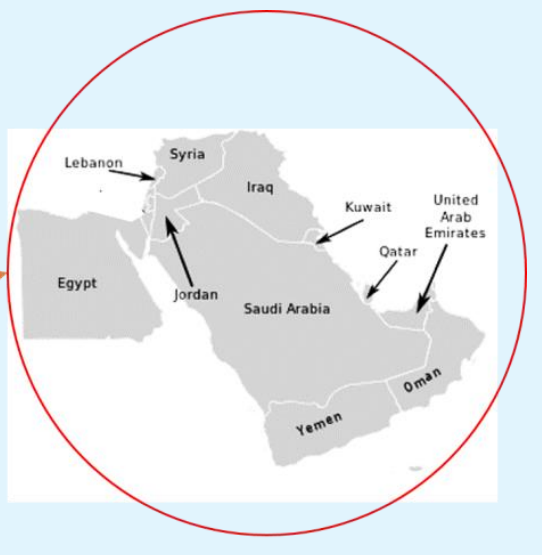

Figure 1: (A) The World map and (B) the Arabian Peninsula countries alongside neighbouring countries.

Water Stress Regions ('000 $\mathrm{m}^{3} /$ Capita/Year)

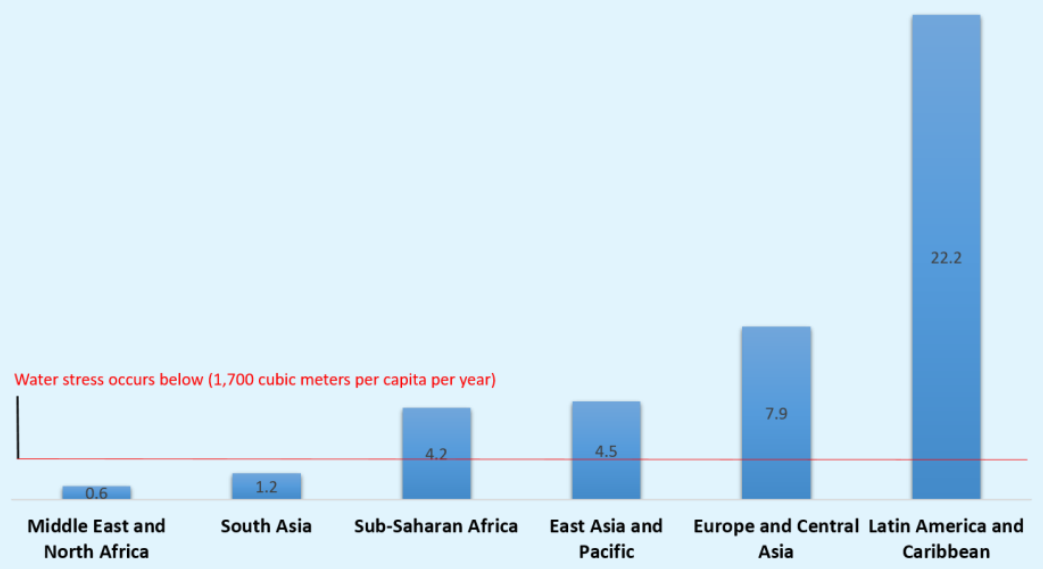

Figure 2: Water stress index in the region. Water stress occurs below 1,700 cubic meters (m3) per capita per year. Source: World Development Indicator (WDI). 
A steady sharp decrease in underground water availability for irrigation has been a major concern in this region. Generally, water use efficiency (WUE) is considerably low in GCC regions under conventional methods [4]. This issue of scarce water resources has been recognized as a major setback to agriculture as the need for water resources keep increasing in these countries to meet regular demand of both agricultural activities and non-agricultural purposes [5].

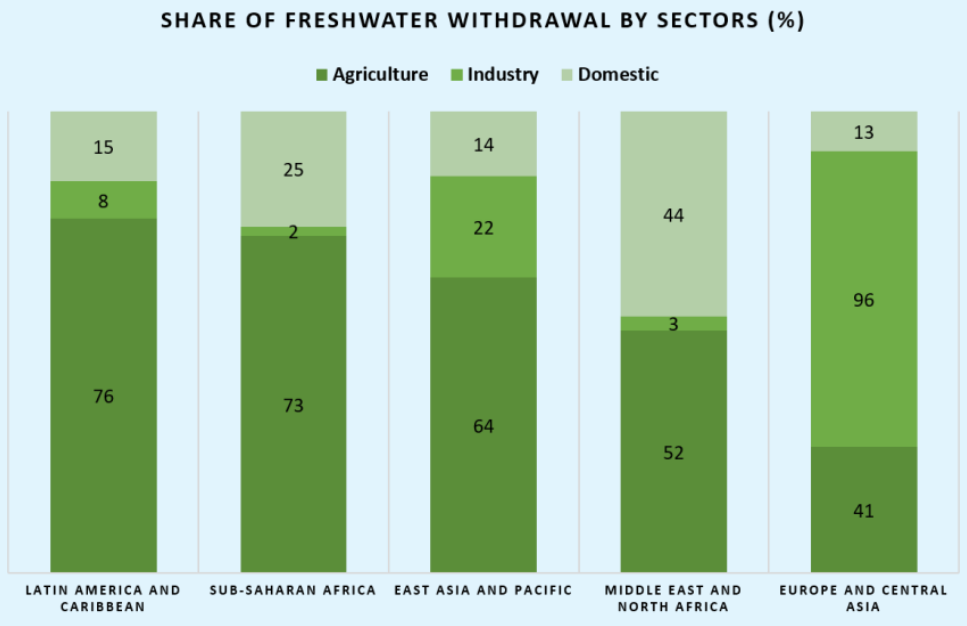

Figure 3: Share of freshwater withdrawals among Agriculture; Industry and Domestic uses in different world regions. Source: World Development Indicator (WDI).

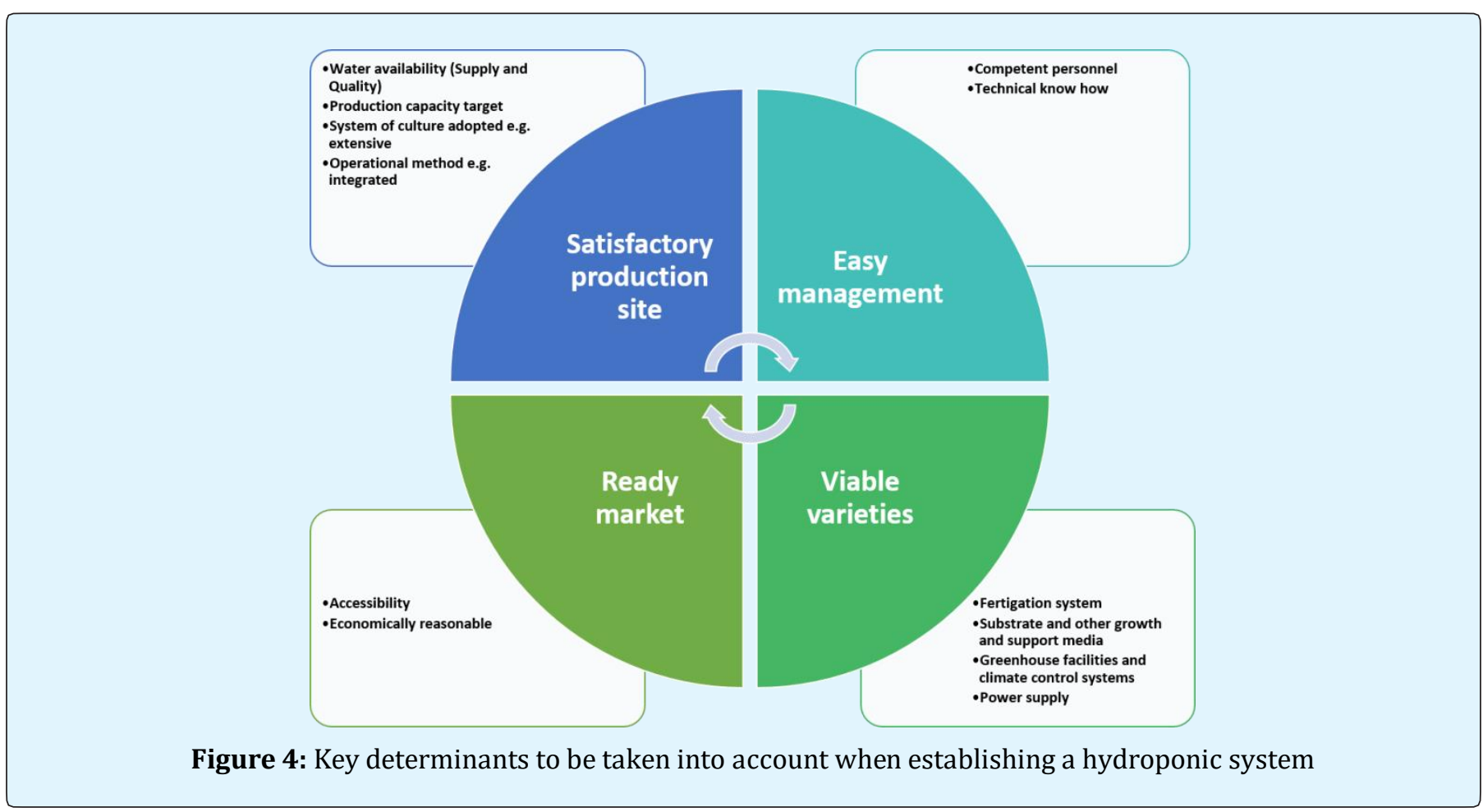

Meanwhile, with conventional agriculture practices, other environmental issues such as pesticides effect in runoff water, deteriorated physical components of the soil and water quality and increase of soil-borne diseases 


\section{Open Access Journal of Agricultural Research}

beside groundwater shortage and non-arable soil are of great concern. Over the past 5 decades, use of pesticide has increased globally by nearly 42 times with the current utilization in the amount of 2.5 million tons annually [6]. Also these constraints, altogether responsible for the reasons why only approximately $36 \%$ of the global land is suitable for crop production [7]. Growing agricultural production capacity, through the use of hydroponic systems, is foreseen as a promising approach to achieve sustainability in agriculture in this region. There are several advantages obtainable by growing agricultural produce hydroponically. Such benefits include but not limited to the efficient water utilization, reduction in pesticides, increased yields and unrestricted production of food compared to conventional agricultural method all the year round [8]. The key determinants to achieve better productivity in hydroponics are satisfactory production site, easy management, viable varieties, and ready market must be considered (Figure 4). The hydroponic system has considerably expanded in the most recent decade as it adds to the escalation of plant production and gives high harvest yields even in zones with unfriendly growing conditions like the Arabian Peninsula countries. In this review, we aim to discuss: 1. the merits of hydroponics compared with the conventional farming method. 2 . The probable limitations that affect the hydroponic system. 3. Nutritional value of phytochemicals accumulation of hydroponic compared to soil grown crops, and 4 . The potential future of the hydroponic system compared to the conventional method in the Arabian Peninsula.

\section{Hydroponic System}

Hydroponic is defined as a method of growing in a soilless condition using liquid chemical fertilizer as a source of nutrient [9]. Most terrestrial crops are grown with their roots submerged directly in the nutrient solution only or alternatively in an inert growth media such as mineral wool, gravel, and perlite $[10,11]$.

\section{Existing Growing Methods}

Growing crops under soilless culture (hydroponics) can be places into two different categories, namely a) liquid culture and b) aggregate culture as summarized the Figure 5.

Solution/Liquid Culture: This growing method is equally known to be the "true Hydroponics" because plants nutrient requirement is supplied in solution form in a constant circular motion after ensuring re-aeration and adjustment of all the necessary parameters such as $\mathrm{pH}, \mathrm{EC}$, as well as levels of the nutrient, a good example is nutrient film technique NFT [12].

Aggregate Culture: In this case, the required nutrient solution is supplied through a specific irrigation designed system to the plants supported in a media that is either organic or inert. Mostly, the unused solution is left to run out as waste if the system is open or recirculated if it is a closed system type. Example of media often used are rock wool, perlite, pumice, etc [12].

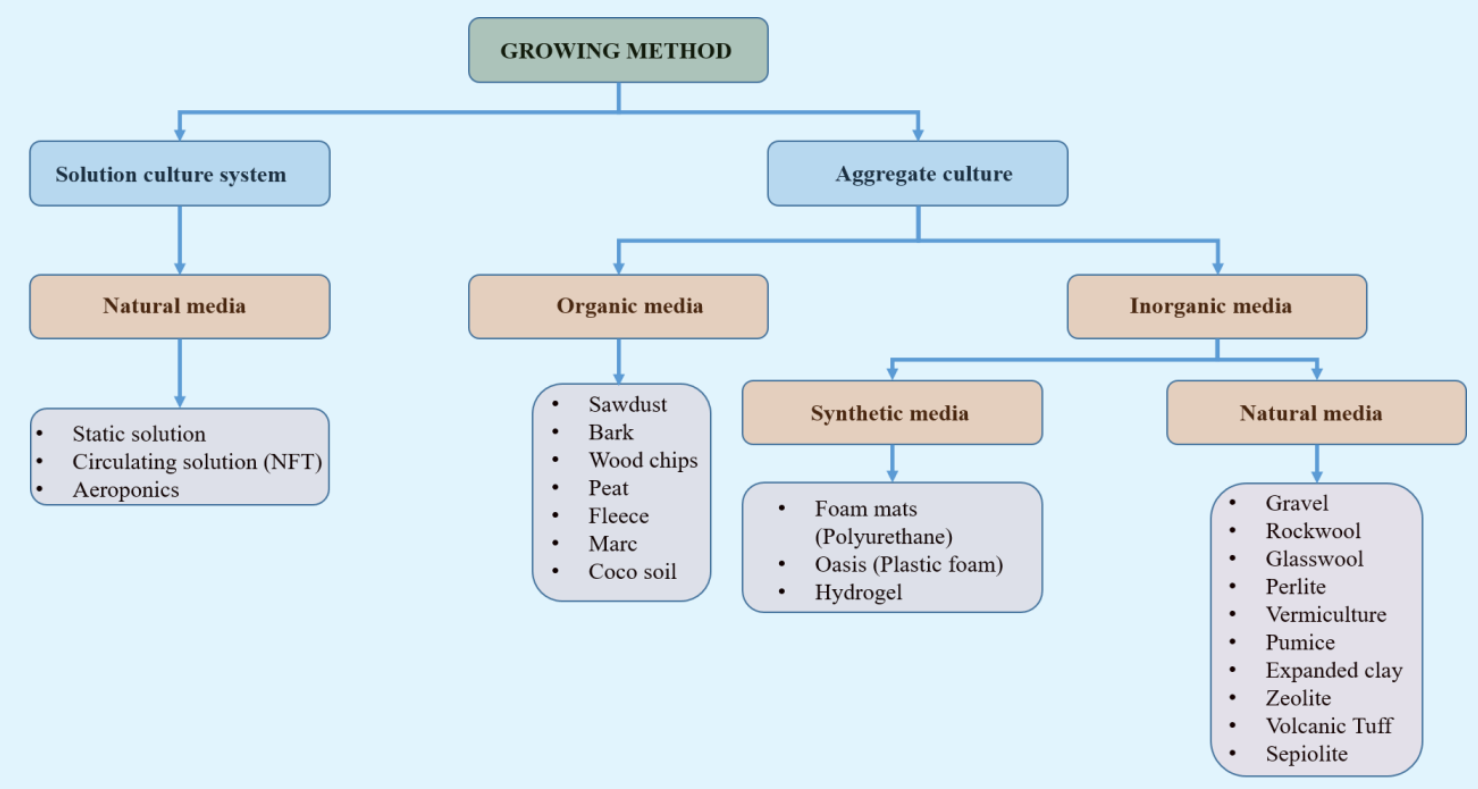

Figure 5: Growing methods in hydroponics as a function of the culture system and used media. 


\section{Open Access Journal of Agricultural Research}

The hydroponic system exists in a few different types such as wick system, ebb, and flow system, drip system, deep water culture system, nutrient filter technique (NTF) system.

Nevertheless, some factors or parameters must be carefully examined while selecting any of the existing technique which includes:

- Space availability and other available resources

- The expected productivity level

- Growing medium, suitable for growth, must be available

- The quality expectation of the output or produce in terms of appearance, colour, size, freedom from infestation from pests; etc.

\section{Different Hydroponics Techniques in Use}

The prevailing hydroponic system for growing crops is classified based on the adopted techniques. A hydroponic technique simply means the adopted style to supply liquid nutrients to the root systems of the plant. The different hydroponic system in use are shown in the Figure 6.

\section{Aeroponic}

This system (Figure 6-A) is the most complex and advanced technology in term of operations and maintenance. The grown plant is placed in special trays in which they are suspended. The nutrient solution is supplied through the spraying method at every minute as regulated by timer targeting the roots system, which gives a thin layer of nutrients. The system is constantly monitored to avoid malfunctioning of the pump at any time.

\section{Wick Technique}

In this system (Figure 6-B) the parts are immobile. The nutrient solution is stored in a reservoir where the oxygen level is maintained by using an air stone placed at the bottom of the reservoir. The nutrient mixture is drawn into the growing media with a wick (plastic tubing). The root system of the crop is embedded in the growing medium [13].

\section{Drip Technique}

The drip system (Figure 6-C) utilization surpasses that of all other systems of hydroponic. Drip system task is somewhat clear - a clock controls a submersed siphon.
The siphon supplies water/supplement through a trickle line that is situated over the plant base and growing medium. Water/supplement trickles to the base of every plant, supplies the root systems with a supplement, and channel through growing medium once more into a store where it will be used again [13].

\section{Ebb and Flow Technique}

The other name for the ebb and flow technique is "flood and drain" (Figure 6-D) technique due to the continuous and orbital rotation of pumping the nutrient solution into the tray that housed the plant and it draining back to the tank [14]. The simple framework of ebb and flow system is made up of a tray that housed the plant containing the growing medium placed above the tank of nutrient solution. A timer is essential to regulate the submerged pump, where nutrient solution forcefully trickled into the tray and recycling back into the tank. The process repeats itself continuously at regulated time intervals.

\section{Water Culture}

System (deep system) (Figure 6-E) originally, virtually all the hydroponic systems emanated from the deep system [15]. This system is well simplified, comprises of tank/reservoir, an air stone place at bottom of the reservoir, a timer and, tubing system, an air pump to facilitate air movement, as well a floating platform [16]. With the progress of air circulation strategies to keep disintegrated oxygen, the profound deep system was developed, thus plants can be cultivated with roots continually suspended in the nutrient solution. To attain optimum growth conditions, it is very crucial to constantly monitor the oxygen, the concentration of nutrient, salinity as well as $\mathrm{pH}$ level [17].

\section{Nutrient Film Technique System (NFT)}

The nutrient film technique (NTF) (Figure 6-F) came to existence to improve on the weakness associated with ebb and flow systems in the 1960s and still remain the universally accepted system among horticulturalist. The nutrient solution in a tank, flow round the whole system via pumping into plant tray at every second, thus constantly circulates around root systems [17]. The collection of the solution back in the reservoir facilitates reused, however, the water volume is regulated by the slant position of the tray as well as the intensity of the water pump. Furthermore, due to the permanent contact of the root systems with water, they are highly susceptible to fungal infestation [18]. 


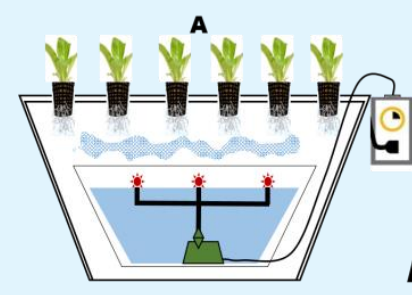

D

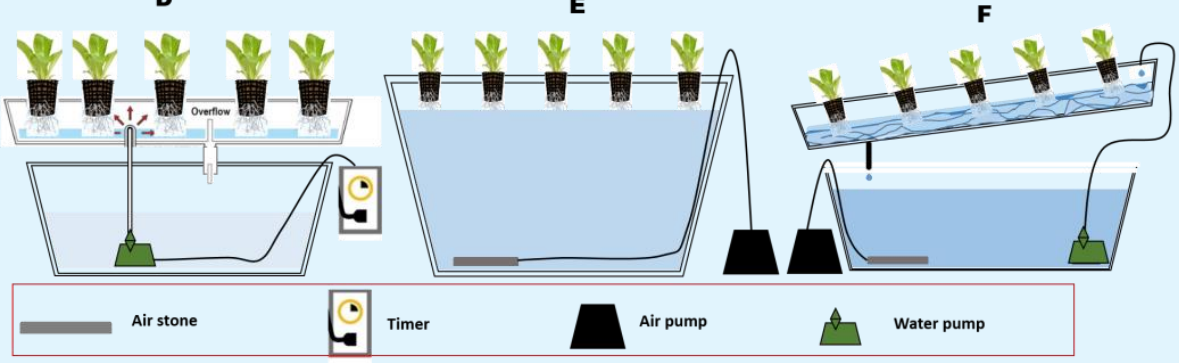

Figure 6: Different types of the hydroponics techniques: A. Aeroponic; B. Wick technique; C. Drip technique; D. Ebb and flow technique; E. Water Culture; F. Nutrient film technique system (NFT) [19].

\section{Nutrient Solution for Hydroponic System}

Crops require essential micro and macro elements for their healthy growth and development. Deficiency of any of the nutrients in crops would affect their life cycles. Adequate nutrient management is very important by the soil less grower in order to maximize production.

\section{Managing Nutrient Solution}

Achieving an optimum in the hydroponic system is very easy; however, inappropriate nutrient solution management can result to poor growth of the plant. Good performance or failure of hydroponic production is therefore, the function of adequate nutrient management plan. The adjustment of the $\mathrm{pH}$ level, the temperature and electrical conductivity of the nutrient solution and prompt replacement when required, will surely result to optimum production.

\section{pH Level of Nutrient Solution}

The alkalinity and acidity of the solution are measured on the $\mathrm{pH}$ scales that range from 1 to 14 . Mostly, the optimum $\mathrm{pH}$ of nutrient solution falls between 5.8 and 6.5 respectively. When the $\mathrm{pH}$ is too high or low against the recommended range for a particular crop, the nutrient will promptly exhibit toxicity symptoms on the crop. Table 3 show different hydroponic crops with different $\mathrm{pH}$ values.

\section{Electrical Conductivity (EC) of Nutrient Solution}

The electrical Conductivity (EC) measures the salinity of the solution. This is achievable with simple measuring instrument; EC meter. The major setback of EC is that the concentration of the individual nutrient constituents cannot be measured separately but rather the total concentration of the solution. The optimum EC range for most crop is between 1.5 and $2.5 \mathrm{dSm}-1$. Table 1 show different hydroponic crops with different $\mathrm{EC}$ values.

Table 1: Optimum range of $\mathrm{EC}$ and $\mathrm{pH}$ values for different crops under various hydroponic techniques

\begin{tabular}{|c|c|c|c|c|c|c|c|}
\hline \multirow{2}{*}{ System } & Crop & EC $(\mathbf{d S m}-\mathbf{1})$ & $\mathbf{p H}$ & $\begin{array}{l}\text { Water use } \\
\text { efficiency }\end{array}$ & Substrate/Media & Country & Reference \\
\hline \multirow{4}{*}{ Aeroponic } & Potato & $2-2.5$ & $5.5-6.5$ & High & Rockwool & Germany & {$[20]$} \\
\cline { 2 - 8 } & Potato & $2-2.5$ & $5.5-6.5$ & High & Perlite & Spain & {$[21]$} \\
\cline { 2 - 8 } & Tomato & $2-2.5$ & $5.5-6.5$ & High & NR & India & {$[22]$} \\
\cline { 2 - 8 } & Lettuce & $0.8-1.2$ & $5.5-6.5$ & High & NR & India & {$[22]$} \\
\hline Wick technique & Lettuce & 0.3 & 5.6 & High & Coconut coir substrate & Brazil & {$[23]$} \\
\hline
\end{tabular}




\section{Open Access Journal of Agricultural Research}

\begin{tabular}{|c|c|c|c|c|c|c|c|}
\hline & $\begin{array}{c}\text { Kalanchoe } \\
\text { blossfeldiana }\end{array}$ & 1.6 & 6.5 & High & Peat moss + Perlite & South Korea & {$[24]$} \\
\hline Drip technique & vegetable crops & NR & NR & High & NR & USA & {$[25]$} \\
\hline $\begin{array}{c}\text { Ebb and flow } \\
\text { technique }\end{array}$ & Pak choi & NR & NR & High & $\begin{array}{c}\text { peat + perlite + organic } \\
\text { fertilizer }\end{array}$ & China & {$[26]$} \\
\hline $\begin{array}{c}\text { Nutrient film } \\
\text { technique }\end{array}$ & Tomato & $2-2.5$ & $5.5-6.5$ & High & Rock wool & Switzerland & {$[27]$} \\
\hline
\end{tabular}

NR - Not Reported

\section{Commercially Grown Crops using Hydroponics}

Virtually all crops can be practically grown under the hydroponic system. However, vegetables, fruits, and ornamental crops are mostly cultivated using these various techniques. Nevertheless, other plants can be cultivated under the system depending on the available resources.

Different type of crops ranging from vegetables, fruits, fodders, cereals as well as medicinal plants have been successfully cultivated under the hydroponic system at indoor and commercial level. The table 2 shows a list of crops grown commercially.

Table 2: Some of economic crops cultivated hydroponically as obtainable from different literatures.

\begin{tabular}{|c|c|c|c|}
\hline Crop Classification & Crop(s) Name & Countries & Reference(s) \\
\hline \multirow{4}{*}{ Cereals } & Maize (Zea mays), & Italy & {$[28]$} \\
\cline { 2 - 4 } & Rice (Oryza sativa) & India & {$[29]$} \\
\cline { 2 - 4 } & Buckwheat (Fagopyrum esculentum) & Japan & {$[30]$} \\
\cline { 2 - 4 } & Millets (Panicum miliaceum) & Indonesia & {$[31]$} \\
\cline { 2 - 4 } & Sorghum (Sorghum bicolor) & China & {$[32]$} \\
\cline { 2 - 4 } & Tomato (Lycopersicon esculentum) & Spain & {$[33]$} \\
\cline { 2 - 4 } & Bell pepper (Capsicum annum) & Brazil & {$[34]$} \\
\cline { 2 - 4 } & Cucumbers (Cucumis sativus) & Iran & {$[35]$} \\
\cline { 2 - 4 } & Melons (Cucumis melo) & Indonesia & {$[36]$} \\
\hline \multirow{5}{*}{ Vegetables } & Radish (Raphanus sativus) & China & {$[37]$} \\
\cline { 2 - 4 } & Lettuce (Lactuca sativa) & China & {$[38]$} \\
\hline \multirow{3}{*}{ Leafy Vegetable } & Spinach & Japan & {$[39]$} \\
\hline \multirow{3}{*}{ Fruits } & Strawberry (Fragaria ananassa) & Spain & {$[40]$} \\
\hline \multirow{3}{*}{ Flower / Ornamental crops } & Raspberries & Portugal & {$[41]$} \\
\cline { 2 - 4 } & Carnations (Dianthus caryophyllus) & Turkey & {$[42]$} \\
\hline \multirow{2}{*}{ Medicinal crops } & Sunflower (Helianthus annuus L.) & Brazil & {$[43]$} \\
\cline { 2 - 4 } & Coleus (Solenostemon scutellarioides) & India & {$[44]$} \\
\cline { 2 - 4 } & Indian Aloe (Aloe vera) & India & {$[44]$} \\
\hline \multirow{2}{*}{ Fodder crops } & Alfalfa (Medicago sativa L.) & China & {$[45]$} \\
\cline { 2 - 4 } & Barley (Hordeum vulgare L.) & China & {$[46]$} \\
\hline \multirow{3}{*}{ Leguminous crops } & Lentil (Lens culinaris) & Pakistan & {$[47]$} \\
\hline & Cowpea (Vigna unguiculata L.) & Greece & {$[48]$} \\
\cline { 2 - 4 } & Chickpea (Cicer arietinum L.) & Australia & {$[49]$} \\
\hline
\end{tabular}

\section{Merits of Hydroponics Compared with Conventional Farming Methods}

Growing plants under hydroponic systems exhibit many advantages over cultivation under soil based culture in several ways [50]. Hence there are several merits of the hydroponic system of growing crop over soil grown crops which include: 


\section{Open Access Journal of Agricultural Research}

\section{It Enhances Productivity}

It is obvious that nutrition control in plants grown under hydroponics is very accurate that mostly lead to high yields with good quality but that does not mean that yield from well managed plants grown conventionally will produce less yield and inferior quality [51].

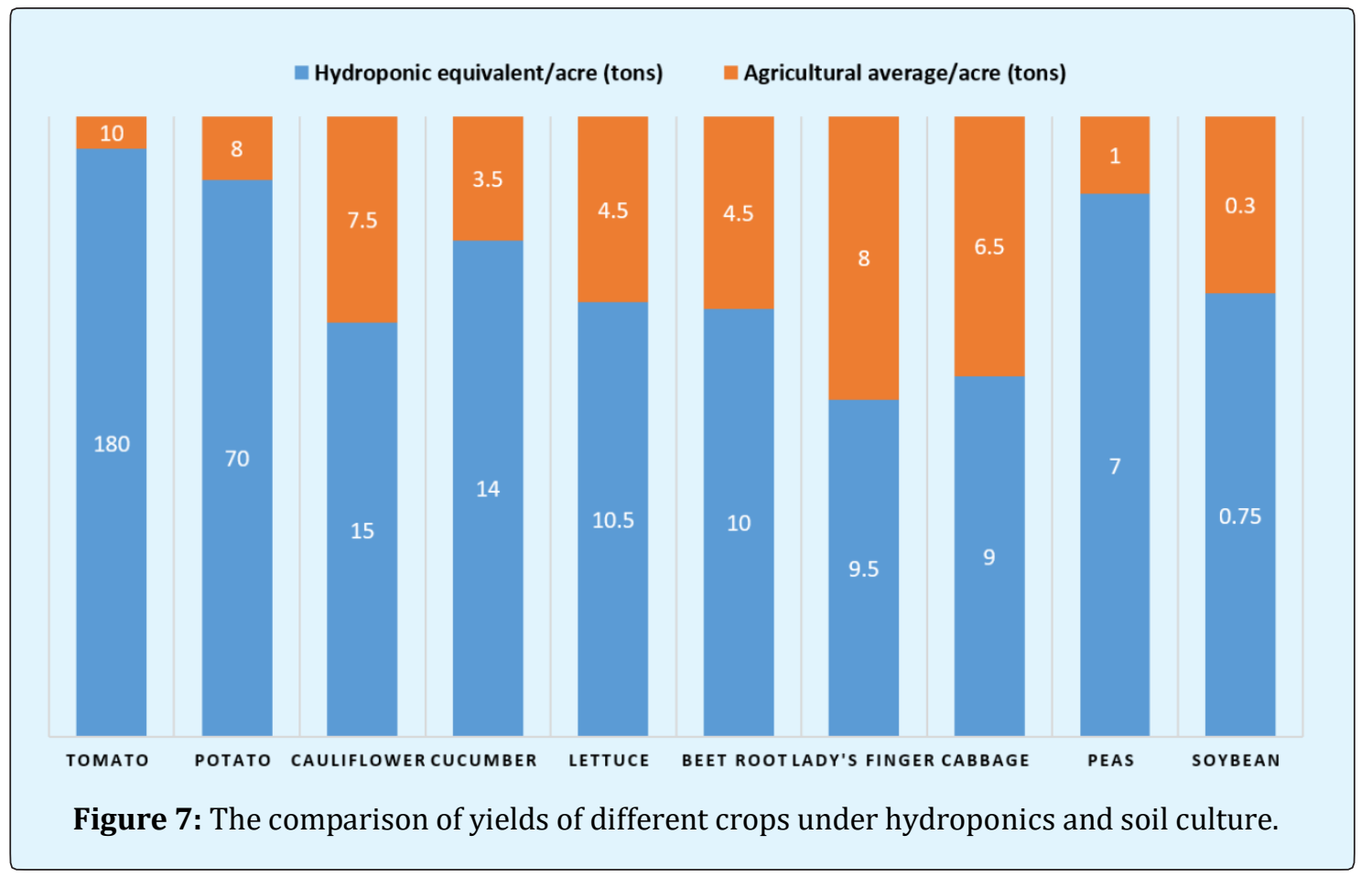

Also, it is very understandable that when soil encountered some problems such as soil toxicities, high soil salinity, and acidity, in that case, hydroponics will produce crops with high yield and better quality. Several studies had been carried out with outcome favouring hydroponics as the best in terms of yield and quality with little efforts when compared with the conventional method [52]. However, it was achievable majorly because growth conditions are more uniform and controllable but this is not controllable in most experiments carried out in the soil. Since hydroponic system enhances plant growth by providing optimal conditions, hence higher yields are obtainable compared to the soil cultivated as illustrated in the Figure 7.

\section{Plant Nutrition Control}

The ability to control plant nutrition accurately is one of the advantages of hydroponics compared to soil grown crops. This is achievable from different angles:

- The concentration control point of view where the applied concentration is regulated to suite different crops need, different environmental factors, plant growth stages, etc. Also, toxic elements such as Mn, B, Z, $\mathrm{Cu}, \mathrm{Pb}$, etc. to plants when exceeding the normal limit can be maintained within concentrations considered safe enough.

- Also, the supply of required nutrient elements uniformly is a guarantee, knowing well which nutrients need to be supplied to the substrate. This is very peculiar to water culture techniques being very advanced in technology compared to aggregate cultures, particularly the drip irrigation system.

- The manager has absolute control over the number of nutrients to be provided when using either water cultures or aggregate cultures with a neutral substrate. Contrarily, this is not achievable under the soil cultures as nutrients could be found in excess within the soils which could lead to high salinity or acidity.

- $\mathrm{pH}$ and EC of nutrient solutions are very controllable under hydroponics grown plants to conform to the nutrient requirement of such crop coupled with environmental factors. However, to achieve the same feet in soil grown crops might be practically impossible and if otherwise, it could be highly expensive. 


\section{Open Access Journal of Agricultural Research}

\section{Water use Efficiency and Control}

Water is one of the most essential resources for bountiful crop production. Cultivation under protected system demand quiet large quantity of water for irrigation due to the lack of enough rainfall for crop good growth performance is needed especially in hot, arid and semi-arid regions of the globe, water has been considered as a major limiting factor to crop production in terms of availability (quantity), quality as well as cost.

The convenient irrigation in hydroponic is a great advantage most especially with some hydroponic systems such as NFT and another related system where there are direct contact of roots with the nutrient solution as well as sub irrigated substrate culture. However, other systems that use organic and inorganic substrate may be deprived of this opportunity as most of the substrates exhibited low water holding capacity when compared to soil.

Considering water use efficiency, some hydroponic systems, particularly those operating under closed systems where nutrients solution is recirculated constantly, the water saving is undisputedly high as drainage and evaporation is properly checked from the surface based on the operation method and designing of the system (NFT - "closed system").

\section{Manpower Requirement Reduction}

In the hydroponics, the headache of normal cultural practices prevalent with soil grown crops such as weeding, soil sterilization, mulching, etc. that requires intensive labour input is mitigated / drastically reduced. However, due to the degree of automation and the kind of substrate used, crop population per substrate have a great influence on the quantity of labour that will be required, the more automation the less labour requirement in term of quantity. In a null shell irrespective of the type of hydroponics system in use, there is still a considerable saving in terms of labour input used in general.

\section{Cultivation all the year round}

The number of harvested crops annually is increased as a result of lack of the growing techniques, several operations such as soil cultivation, sterilization of soil, etc. as applicable in a chosen area of production since the interval in duration between crops is practically negligible.

\section{Unproductive soil}

A good alternative is provided by hydroponics in terms of idea crop to soil culture particularly in the situation where the soil availability is practically zero, not fertile enough to support cultivation, water lodged soil with poor aeration soil, saline soil (with high salinity), the sol is considered toxic as a result of accumulation of heavy metals (eg. lead, mercury, cadmium, etc) and high infestation of different soil pathogen resulted from accumulation in the soil.

\section{Root System Environment Well Control}

The beauty of accurately controlling the temperature around the root, root oxygen supply are essential factors that relative achievable with ease in hydroponic systems.

\section{Setback Associated with Hydroponics System}

\section{High Capital Investment Cost}

The initial cost of investment in a hydroponics system could be enormous as acquiring inputs, setup cost (construction), system maintenance when compared with conventional and primitive soil cultivation. The hydroponics system in use will determine the rate at which input increases and equally the level of automation in terms of accuracy in control measure adopted by any system, i.e. it is costlier to set up NFT compared to the other system such as rook wool system, but on the long run the running cost per annum is considerably lower in NFT than in the rook wool system.

Depending on the types of used materials, NFT system that comprises of metal trays and supported with stands is far costlier than the one in which corrugated asbestos sheets for production of lettuce under NFT system etc. The different countries' economies play a vital role in determining the actual cost of materials as this may vary from country to country, for example, the cost of perlite is relatively cheap in Greece but on contrary very expensive in the UK.

\section{Technical Know-How Demands}

The successful operation of hydroponic system greatly depends on the fast knowledge and ability to learn the best way to cultivate various crops, physiology of plant, basic elementary chemical processes, quick detection of disease symptoms as well as good understanding of the 


\section{Open Access Journal of Agricultural Research}

control system, etc. Due to the sophistication of hydroponics, it is certain that its operation is not quite easy. Also, the support and assistant of technical experts, researchers, entrepreneur dealing with installation and different accessories, government institution should be sorted from time to time.

Crops cultivation under controlled volume demands skilful management system. Rewarding commercial hydroponics requires prompt attention of professional staff with good management skills. Hence, the handlers must be versatile with deep knowledge and several skills to give him the edge to handle multiple tasks such as preparation and regulating the nutrient solution when needed, monitor and control electro - computer devices, understand plant physiology, ability to detect and control prevailing diseases.

More attention needs to be paid to nutrient solution composition and supply, pH, EC as a slight mistake could be detrimental to crops in hydroponics [11,53]. Power and water supply are expected to be constant, any failure in supply could injurious or total loss of the crops [54].

\section{Disease Risk}

Hydroponically grown crops are prone to disease infections if extra care is not taking. In the "open system," disease infection risk is considerably low because nutrient solution and water drain away freely living the crop root less prone to disease attack [55] However, in contrary, crops grown under "closed system" are prone to disease infections because excess drain continuously flows through the roots of the plant in a circular pattern, once there is any traces of disease causative pathogen in the system, the whole plants may suffer terrific infection attack [54].

\section{Nutritional Value of Phytochemicals Accumulation of Hydroponic Compared to Soil Grown Crops}

The conventional system of agriculture, soil health variation, and fluctuation in environmental factors are among the limitations in the soil cultivation systems. Such factors as water type, temperature variation as well as humidity are stressors that can affect crops by causing possible alteration in their phytochemical makeup irrespective of cultivation method adopted. Due to these variability, several studies have been conducted to compare the nutritional contents of crop cultivated hydroponically to soil cultivated with various results, while some studies showing significant difference between the two methods, others showing hydroponic systems is better that soil cultivated crops or vice versa and some show no distinctive differences between the two in the tested nutrient levels. However, it should be noted that the experimental outcomes could be greatly influenced by the experimental design as well as variability in various conditions hence affecting the final outcome of the studies.

The hydroponically grown crops particularly vegetables have been established by several studies to produce high quality product when compared to conventionally produced ones [56,57]. According to Murphy MT, et al., Rouphael Y, et al., Treftz C, et al., [5860], the conducted studies have shown no significant differences between hydroponic and soil cultivated vegetables in terms of their qualities. Summarily, the majority of the authors are of opinion that hydroponic systems of cultivation are one of the best options in the extreme environment or arid regions where fertile soil is not available or the available types may not support the healthy growth of the crop.

Nevertheless, despite the different and divergent views, the researchers tend to support the general opinion that possibly hydroponic system can elevate the content of various phytochemical compounds in crops. The hydroponic systems have produced high quality fresh vegetables showing higher nutritional value as a result of a high build-up of phytochemical compounds as recently established by different studies, as clearly indicated in the Table. 2.

A study conducted by Premuzic, et al. [61] discovered that hydroponically cultivated tomatoes have an incremental of antioxidants as well as macro- and micronutrients, compared to soil cultivated tomatoes. Also, in Achillea millefolium it was established that the build - up of flavonoid is higher in the hydroponically cultivated plants $(0.43 \%$ dry weigh) compared to the soil - based production $0.38 \%$ dry weight) [62]. In addition, flavonoids accumulation in the cultivated plants under hydroponic systems was found to exhibit tremendous improvement in the activity of the antioxidant of aqueous as well as lipids extracts, not only that, ascorbic acid, vitamin E, lipoid acid, total phenols, and rosmarinsic contents are increasing steadily. Furthermore, more findings in various studies revealed the accumulation of phytochemical compounds under soilless culture method as shown in the Table 3. 
Table 3: Nutritional value of phytochemicals accumulation of hydroponic compared to soil grown crops.

\begin{tabular}{|c|c|c|c|c|}
\hline Crop(s) & Phytochemicals & Hydroponically grown crop(s) & Soil grown crop(s) & Reference(s) \\
\hline \multirow[t]{2}{*}{ Tomato } & Lycopene & $\begin{array}{l}\text { No significant differences was } \\
\text { observed (average content } 36.15 \\
\mu \mathrm{g} \text { ) }\end{array}$ & $\begin{array}{l}\text { No significant differences was } \\
\text { observed (average content } 36.25 \\
\mu \mathrm{g} \text { ) }\end{array}$ & [63] \\
\hline & Ascorbic acid & $\begin{array}{l}\text { The ascorbic acid value recorded } \\
\text { was higher }(13.3 \mathrm{mg} / 100 \mathrm{ml})\end{array}$ & $\begin{array}{l}\text { The recorded was lesser }(0.693 \\
\mathrm{g} / 100 \mathrm{ml})\end{array}$ & [64] \\
\hline Onion & Total flavonoids & No significant difference observed & No significant difference observed & [65] \\
\hline \multirow{3}{*}{ Basil } & $\begin{array}{c}\text { Ascorbic acid } \\
\text { Vitamin E }\end{array}$ & \multirow{3}{*}{$\begin{array}{l}\text { All of these phytochemicals were } \\
\text { more improved in content under } \\
\text { the hydroponic }\end{array}$} & \multirow{3}{*}{$\begin{array}{l}\begin{array}{l}\text { The contents } \\
\text { phytochemicals }\end{array} \\
\begin{array}{l}\text { were } \\
\text { improved }\end{array}\end{array}$} & \multirow{3}{*}{ [66] } \\
\hline & $\begin{array}{c}\text { Lipoic acid } \\
\text { Total phenol }\end{array}$ & & & \\
\hline & Rosmarinic acid & & & \\
\hline \multirow{4}{*}{ Lettuce } & Alpha-tocopherol & The levels were higher & The levels were lower & [67] \\
\hline & Lutein & \multirow{3}{*}{$\begin{array}{l}\text { These were lesser as a result of } \\
\text { less exposure to the sunlight }\end{array}$} & \multirow{3}{*}{$\begin{array}{l}\text { The exposure to the sunlight is } \\
\text { very high which contributed } \\
\text { greatly the higher deposition of } \\
\text { these phytochemicals when } \\
\text { compared to the hydroponic }\end{array}$} & \multirow{3}{*}{ [68] } \\
\hline & $\begin{array}{c}\text { Beta-carotene } \\
\text { Violaxanthin } \\
\end{array}$ & & & \\
\hline & Neoxanthin & & & \\
\hline \multirow{2}{*}{ Red paprika } & Carotenoids & $\begin{array}{l}\text { Was higher in terms of dry weight } \\
\text { (4.5 mg/ } 100 \mathrm{~g} \text { dry weight) }\end{array}$ & $\begin{array}{l}\text { It was relatively lesser }(2.81 \mathrm{mg} / \\
100 \mathrm{~g} \text { dry weight }\end{array}$ & \multirow{2}{*}{ [69] } \\
\hline & Capsanthin & $\begin{array}{l}\text { Was higher in terms of dry weight } \\
\text { ( } 46.74 \mathrm{mg} / 100 \mathrm{~g} \text { dry weight) }\end{array}$ & $\begin{array}{l}\text { It was relatively lesser }(29.57 \mathrm{mg} \\
/ 100 \mathrm{~g} \text { dry weight }\end{array}$ & \\
\hline Strawberries & Ascorbic acid & The content was higher & The content was lesser & [60] \\
\hline Raspberries & & The content was higher & The content was lesser & [60] \\
\hline \multirow{5}{*}{ Sweet potato } & Ascorbic acid & \multirow{5}{*}{$\begin{array}{l}\text { The content of the } \\
\text { phytochemicals were found to be } \\
\text { relatively higher. }\end{array}$} & \multirow{5}{*}{$\begin{array}{l}\text { The content of the } \\
\text { phytochemicals were found to be } \\
\text { relatively lesser compared to } \\
\text { hydroponically grown sweet } \\
\text { potato. }\end{array}$} & \multirow{5}{*}[70]{} \\
\hline & Carotene & & & \\
\hline & $\frac{\text { Thiamin }}{\text { Oxalic }}$ & & & \\
\hline & Tannic acids & & & \\
\hline & Chymotrypsin & & & \\
\hline
\end{tabular}

\section{The Future Potential of the Hydroponics in Arabian Peninsula}

The advanced technology of hydroponic system is growing at alarming rate in the agricultural sector across all the Arabia peninsula countries, and no doubt it has the potential to dominate the future food production [71]. The population keep growing and the land availability declines because of the pressure exerted from the construction of infrastructures coupled with the uncultivable of the arid lands. Due to this facts, the best alternative is to employ new technologies such as hydroponics in order to enhance food production [72]. However, to better understand the hydroponic potential in the future is important to critically examine the earlier users of this technology [73]. Good example is the adoption of the technology in the Tokyo, Japan where the availability of arable land is relatively scarce because of the high population but opted for hydroponic system in rice production to feed the growing population and to preserve the valuable land [74]. Also, the technology was successful adopted in the food production in Israel that is characterized with dry and arid climate. The huge initial capital outlay of hydroponic system will soon vanish as it is peculiar with most technologies when newly invented on the long run, thereby creating easy accessibility to the technology. Well-constructed and managed hydroponics has the potential to take care of crop production to feed the growing population of Arabian Peninsula countries that is characterized with impoverish soil and water scarcity.

\section{Conclusion}

The Arabian Peninsula countries had recently experienced astonishing development both socially and economically. The food availability produced from local production with known constraint of water resources and 


\section{Open Access Journal of Agricultural Research}

uncultivable land is far less to meet the daily requirements, as adversely affecting the agricultural productivity. Hence, attaining sustainability in terms of crop production, land usage and water consumption must be improved. However, the persistent gap between water demand and the agricultural crop production would be taken care of by embracing the modern technologies particularly hydroponic system. Hydroponics is an innovation with different kinds of technologies which uses is being developed for future space travel as well as in arid and semi-arid land. No doubt, hydroponics is quickly picking up force and fame and quickest growing alternative system of agriculture. This study exhibited a general understanding about the importance of hydroponics, its advantages against soil culture system, possible associated limitations, and nutritional value of phytochemical compounds accumulation of hydroponic compared to soil grown crops. Considering the aforementioned facts, vegetables produced hydroponically seems to be an important instrument to have crops with high accumulation of phytochemical compounds leading to an increase in the nutritional quality of the vegetable. In addition, by improving and investing heavily on hydroponic system will lead to the food secured countries. Adequate policy must be equally put in place.

\section{References}

1. Pardey PG, Beddow JM, Hurley TM, Beatty TKM, Eidman VR (2014) A Bounds Analysis of World Food Futures: Global Agriculture Through to 2050. Australian Journal of Agricultural and Resource Economics 58(4): 571-589.

2. Badami MG, Ramankutty N (2015) Urban agriculture and food security: A critique based on an assessment of urban land constraints. Global Food Security 4: 815.

3. Pirani SI, Arafat HA (2016) Interplay of food security, agriculture and tourism within GCC countries. Global Food Security 9: 1-9.

4. Al Ajmi A, Salih AA, Kadim I, Othman Y (2009) Yield and water use efficiency of barley fodder produced under hydroponic system in GCC countries using tertiary treated sewage effluents. Journal of phytology $1(5)$.

5. Al-Karaki GN, Al-Hashimi M (2012) Green Fodder Production and Water Use Efficiency of Some Forage
Crops under Hydroponic Conditions. ISRN Agronomy 5.

6. BeVier G (2012) Global food systems: feeding the world. Reprod Domest Anim 47 (4): 77-79.

7. FAO (2016) Food and Agriculture Organization "Database on Arable Land."

8. Barbosa G, Gadelha F, Kublik N, Proctor A, Reichelm L, et al. (2015) Comparison of land, water, and energy requirements of lettuce grown using hydroponic vs. conventional agricultural methods. International journal of environmental research and public health 12(6): 6879-6891.

9. Beibel JP (1960) Hydroponics-The Science of Growing Crops Without Soil. Florida Department of Agric. Bull. pp: 180.

10. Maharana L, Koul D (2011) The emergence of Hydroponics. Yojana 55: 39-40.

11. Resh HM (2016) Hydroponic Food Production: A Definitive Guidebook for the Advanced Home Gardener and the Commercial Hydroponic Grower CRC Press, $7^{\text {th }}$ (Edn.), pp: 560.

12. Mamta DS, Shraddha VA (2013) A Review On Plant Without Soil - Hydroponics. International Journal of Research in Engineering and Technology 2(3).

13. Ernst JV, Busby JR (2009) Hydroponics: content and rationale: technology is diverse enough in nature that it can be addressed by a variety of content areas, serving as a true integrator. The Technology Teacher 68(6): 20-25.

14. Jones JB Jr (2016) Hydroponics: a practical guide for the soilless grower: CRC press. Technology \& Engineering, pp: 440.

15. Harris D (1988) Hydroponics; the complete guide to gardening without soil.

16. Hoagland DR, Arnon DI (1950) The water-culture method for growing plants without soil. Circular. California agricultural experiment station, $2^{\text {nd }}$ (Edn.), 347: 32.

17. Domingues DS, Takahashi Hideaki W (2012) Automated system developed to control $\mathrm{pH}$ and concentration of nutrient solution evaluated in hydroponic lettuce production. Computers and electronics in agriculture 84: 53-61. 


\section{Open Access Journal of Agricultural Research}

18. Thinggaard K, Middelboe A (1989) Phytophthora and Pythium in pot plant cultures grown on ebb and flow bench with recirculating nutrient solution. Journal of Phytopathology 125(4): 343-352.

19. Lee S, Lee J (2015) Beneficial bacteria and fungi in hydroponic systems: types and characteristics of hydroponic food production methods. Scientia Horticulturae 195: 206-215.

20. Abdullateef S, Böhme M, Pinker I (2010) Potato minituber production at different plant densities using an aeroponic system. Paper presented at the XXVIII International Horticultural Congress on Science and Horticulture for People (IHC2010): International Symposium on 927, pp: 429-436.

21. Farran I, Mingo-Castel AM (2006) Potato minituber production using aeroponics: effect of plant density and harvesting intervals. American Journal of Potato Research 83(1): 47-53.

22. Gopinath P, Vethamoni P, Gomathi M (2017) Aeroponics Soilless Cultivation System for Vegetable Crops. Chem. Sci. Rev. Lett 6(22): 838-849.

23. Ferrarezi RS, Testezlaf R (2016) Performance of wick irrigation system using self-compensating troughs with substrates for lettuce production. Journal of plant nutrition 39(1): 147-161.

24. Son J, Oh M, Lu Y, Kim K, Giacomelli GA (2006) Nutrient-flow wick culture system for potted plant production: System characteristics and plant growth. Scientia Horticulturae 107(4): 392-398.

25. Hartz T (1996) Water management in drip-irrigated vegetable production. HortTechnology 6(3):165-167.

26. Li M, Wang X, Zhang J (2018) Effects of plug tray immersion time on nitrogen leaching and mini Pakchoi growth under ebb and flow irrigation system. Horticult Int J 2(6): 325-330.

27. Schmautz Z, Loeu F, Liebisch F, Graber A, Mathis A, et al. (2016) Tomato productivity and quality in aquaponics: comparison of three hydroponic methods. Water 8(11): 533.

28. Trevisan S, Manoli A, Quaggiotti S (2019) A Novel Biostimulant, Belonging to Protein Hydrolysates, Mitigates Abiotic Stress Effects on Maize Seedlings Grown in Hydroponics. Agronomy 9(1): 28.
29. Lima JM, Nath M, Dokku P, Raman K, Kulkarni K, et al. (2015) Physiological, anatomical and transcriptional alterations in a rice mutant leading to enhanced water stress tolerance. AoB Plants 7.

30. Matsuura H, Inanaga S, Murata K (2005) Differences in the vegetative growth between common and Tartary buckwheat in saline hydroponic culture. Plant production science 8(5): 533-538.

31. Karjunita N, Khumaida N, Ardie SW (2019) Different Root Anatomical Changes in Salt Tolerant-and Salt Sensitive Foxtail Millet Genotypes. AGRIVITA, Journal of Agricultural Science 41(1): 166-168.

32. Zou G, Zhou L, Zhai G, Ding Y, Lu P, et al. (2019) A high throughput method for screening deep-seeding tolerance in sorghum. Genetic Resources and Crop Evolution 66(8): 1643-1651.

33. Baghour M, Gálvez FJ, Sánchez ME, Aranda MN, Venema K, et al. (2019) Overexpression of LeNHX2 and SISOS2 increases salt tolerance and fruit production in double transgenic tomato plants. Plant physiology and biochemistry 135: 77-86.

34. Lima NdS, Morais MBd, Silva ÊFdF, Camara TR, Willadino L (2017) Production and antioxidative metabolism in bell pepper grown with saline water in hydroponic system. Revista Brasileira de Engenharia Agrícola e Ambiental 21(10): 675-680.

35. Azarmi R, Tabatabaei SJ, Chaparzadeh N (2018) Interactive effects of $\mathrm{Mg}$ and shading on the yield, physiology and antioxidant activity in cucumber grown in hydroponics. Journal Plant Process Function 22(6): 63-72.

36. Christy J, Putri LAP, Hanafiah DS (2018) A Study of Hydroponic Melon Cultivations With Several Substrate Media And Varieties. Journal of Community Research and Service 1(2): 92-96.

37. Hong Z, Yurou C (2018) Effects of Exogenous Cobalt on Seed Germination and Antioxidant Ability of Radish Under NaCl Stress. Northern Horticulture (9): 3.

38. Yan D, Wang S, Ding K, He Y, Fan L, et al. (2019) Strontium Uptake and Effect in Lettuce and Radish Cultivated Under Hydroponic Conditions. Bulletin of environmental contamination and toxicology 103(3): 453-460. 


\section{Open Access Journal of Agricultural Research}

39. Watanabe S, Ohtani Y, Aoki W, Uno Y, Sukekiyo Y, et al. (2018) Detection of betacyanin in red-tube spinach (Spinacia oleracea) and its biofortification by strategic hydroponics. PloS one 13(9): e0203656.

40. Sánchez-Rodas D, Mellano F, Martínez F, Palencia P, Giráldez I, et al. (2016) Speciation analysis of Seenriched strawberries (Fragaria ananassa Duch) cultivated on hydroponics by HPLC-TR-HG-AFS. Microchemical Journal 127: 120-124.

41. Ramos C, Nóbrega L, Baras K, Gomes L (2019) Experimental NFT hydroponics system with lower energy consumption. 5th Experiment International Conference (exp. at'19), Funchal (Madeira Island), Portugal.

42. Aydinsakir K, Tuzel IH, Buyuktas D (2011) The effects of different irrigation levels on flowering and flower quality of carnation (Dianthus caryophllus L.) irrigated by drip irrigation. African Journal of Biotechnology 10(66): 14826-14835.

43. Santos J, Gheyi H, Cavalcante A, Francilino A, PerezMarin A (2016) Growth of ornamental sunflowers under saline stress in hydroponic system of low cost. IRRIGA 21(3): 591-604.

44. Rachappanavar V, Kumar V, Deepa M (2019) Hydroponics in Medicinal and Aromatic Plants. Chapter-2, Chief Editor, 23.

45. Cong L, Sun Y, Wang Z, Kang J, Zhang T, et al. (2018) A rapid screening method for evaluating resistance of alfalfa (Medicago sativa L.) to Fusarium root rot. Canadian Journal of Plant Pathology 40(1): 61-69.

46. Wang Q, Sun G, Ren X, Wang J, Du B, et al. (2017) Detection of QTLs for seedling characteristics in barley (Hordeum vulgare L.) grown under hydroponic culture condition. BMC genetics 18(1).

47. Aslam M, Maqbool MA, Zaman QU, Shahid M, Akhtar MA, et al. (2017) Comparison of different tolerance indices and PCA biplot analysis for assessment of salinity tolerance in lentil (Lens culinaris) genotypes. International Journal of Agriculture and Biology 19(3).

48. Savvas D, Ntatsi G, Vlachou M, Vrontani C, Rizopoulou E, et al. (2017) Impact of different rhizobial strains and reduced nitrogen supply on growth, yield and nutrient uptake in cowpea grown hydroponically. International Symposium on New Technologies for
Environment Control, Energy-Saving and Crop Production in Greenhouse and Plant.

49. Amalraj A, Taylor J, Sutton T (2019) A hydroponics based high throughput screening system for Phytophthora root rot resistance in chickpea (Cicer arietinum L.). Plant methods 15(1).

50. Savvas D (2003) Hydroponics: A modern technology supporting the application of integrated crop management in greenhouse. Food, Agriculture \& Environment 1(1): 80-86.

51. Stoughton RH (1969) Soilless cultivation and its application to commercial horticultural crop production.Trove, Rome.

52. Silberbush M, Ben-Asher J (2001) Simulation study of nutrient uptake by plants from soilless cultures as affected by salinity buildup and transpiration. Plant and soil 233(1): 59-69.

53. Leonhardt KW, McCall WW (1914) Hydroponics. Hawaii Cooperative Extension Service, Hawaii.

54. Jensen M (2013) What is hydroponics? Controlled environment agriculture center. Arizona Board of Regents, Univeristy of Arizona, Tucson, AZ.

55. Jensen MH (1999) Hydroponics Worldwide -A Technical Overview. Acta Hortic 481: 719-730.

56. Maboko MM, Du Plooy CP, Bertling I (2009) Comparative Performance of Tomato Cultivars in Soilless Vs. in-Soil Production Systems. Acta Hortic. 843: 319-326.

57. Palermo M, Paradiso R, De Pascale S, Fogliano V (2011) Hydroponic cultivation improves the nutritional quality of soybean and its products. Journal of agricultural and food chemistry 60(1): 250255.

58. Murphy MT, Zhang F, Nakamura YK, Omaye ST (2011) Comparison between Hydroponically and Conventionally and Organically Grown Lettuces for Taste, Odor, Visual Quality and Texture: A Pilot Study. Food and Nutrition Sciences 2(2): 124-127.

59. Rouphael Y, Colla G (2005) Growth, yield, fruit quality and nutrient uptake of hydroponically cultivated zucchini squash as affected by irrigation systems and growing seasons. Scientia Horticulturae 105(2): 177195. 
60. Treftz C, Omaye ST (2015) Nutrient Analysis of Soil and Soilless Strawberries and Raspberries Grown in a Greenhouse. Food and Nutrition Sciences 6(9): 805815.

61. Premuzic Z, B. M., Garcia A, Rendina A, Iorio A. (1998). Calcium, iron, potassium, phosphorus, and vitamin $C$ content of organic and hydroponic tomatoes. HortScience 33(2): 255-257.

62. Pedneault K, Léonhart S, Gosselin A, Papadopoulos AP, Dorais M, et al. (2002) Variations in Concentration of Active Compounds in Four Hydroponically-and Field-Grown Medicinal Plant Species. Acta Hortic 580: 255-262.

63. Simitchiev H, Kanazirska V, Popov I, Atanasov N (1983). "Biological effect of greenhouse tomatoes grown in rockwool". Acta Horticulturae 133: 59-66.

64. Alan R, Zulkadir A, Padem H (1993) The influence of growing media on growth, yield and quality of tomato grown under greenhouse conditions. II Symposium on Protected Cultivation of Solanacea in Mild Winter Climates 366.

65. Thompson L, Morris J, Peffley E, Green C, Pare P, et al. (2005) Flavonol content and composition of spring onions grown hydroponically or in potting soil. Journal of Food Composition and Analysis 18(7): 635645.

66. Sgherri C, Cecconami S, Pinzino C, Navari-Izzo F, Izzo R (2010) Levels of antioxidants and nutraceuticals in basil grown in hydroponics and soil. Food Chemistry 123(2): 416-422.

67. Buchanan DN, Omaye ST (2013) Comparative Study of Ascorbic Acid and Tocopherol Concentrations in
Hydroponic- and Soil-Grown Lettuces. FNS 4(10): 1047-1053.

68. Kimura M, Rodriguez-Amaya DB (2003) Carotenoid composition of hydroponic leafy vegetables. J agricFood chem 51(9): 2603-2607.

69. Ji-Sun Kim CGA, Jong-Suk P, Yong Pyo L, Suna Kim (2016) Carotenoid profiling from 27 types of paprika (Capsicum annuum L.) with different colors, shapes, and cultivation methods. Food Chemistry 201: 64-71.

70. Ajlouni SK, Masih L (2001) LYCOPENE CONTENT IN HYDROPONIC AND NON-HYDROPONIC TOMATOES DURING POSTHARVEST STORAGE. Food Australia 53(5): 195-196.

71. Moustafa A, Al-Shankiti A, Nejatian A (2011) Potential of protected agriculture to enhance water and food security in the Arabian Peninsula. Proceedings of the Tenth International Conference on Development of Drylands, Cairo, Egypt.

72. Belgacem AO, Nejatian A, Salah MB, Moustafa A (2017) Water and food security in the Arabian Peninsula: Struggling for more actions. J. Exp. Biol. Agric. Sci., 5: S50-S62.

73. Sardare MD, Admane SV (2013) A review on plant without soil-hydroponics. IJRET 2(3): 299-304.

74. De Kreij C, Voogt W, Baas R (1999) Nutrient Solutions and Water Quality for Soilless Cultures. Naaldwijk: Research Station for Floriculture and Glasshouse Vegetables (PBG) Brochure. 